\title{
KEBIASAAN MENULIS BUKU HARIAN DENGAN MENGGUNAKAN MODEL PEMBELAJARAN PROBLEM BASED LEARNINGPADA SISWA KELAS VII SMP MUHAMMADIYAH 2 MEDAN TAHUN PEMBELAJARAN 2017/2018
}

\section{Oleh:}

\author{
OKTAVIA LESTARI P (oktavialestari1990@yahoo.com) \\ Dosen FKIP Prodi Pendidikan Bahasa dan Sastra Indonesia, \\ Universitas Muhammadiyah Sumatera Utara
}

\begin{abstract}
ABSTRAK
Penelitian ini bertujuan untuk mengetahui kebiasaan menulis buku harian dengan menggunakan model problem based learning oleh siswa kelas VII SMP Muhammadiyah 2 Medan Tahun Pembelajaran 2017/2018 yang berjumlah 68 orang siswa yang terdiri dari dua kelas. Untuk menentukan sampel, peneliti menggunakan teknik random sampling atau acak kelas sehingga diperoleh kelas eksperimen, yaitu kelas VII-1 yang berjumlah 38 siswa dan kelas kontrol, yaitu kelas VII-2 yang berjumlah 30 siswa.

Metode yang digunakan dalam penelitian ini adalah metode eksperimen. Alatpengumpulan data adalah tes esai yaitu menulis buku harian. Variabel dalam penelitian ini adalah variabel VII-1 yaitu kemampuan menulis buku harian dengan menggunakan model pembelajaran Problem Based Learning dan variabel VII-2 tanpa menggunakan model Problem Based Learning.

Kemampuan menulis buku harian dengan menggunakan model pembelajaran Problem Based Learning pada kelas eksperimen mendapatkan nilai rata-rata 83,84 dengan persentase nilai 66-79 yang berjumlah 15 orang atau 39,47\% dikategorikan baik. Sedangkan pada kelas kontrol yang menggunakan metode ceramah mendapatkan nilai rata-rata 63 dengan persentase nilai 4054 yang berjumlah 10 orang atau 33,33\% dikategorikan kurang.

Berdasarkan hasil perhitungan uji hipotesis, diperoleh thitung $=13,44$. Selanjutnya harga thitung ini dibandingkan dengan harga ttabel dengan taraf signifikan $\alpha=0,05 \mathrm{dan} \mathrm{dk}=38+30-$ $2=66$ maka diperoleh ttabel $=1,997$. Dengan demikian dapat dikatakan thitung < ttabel yaitu 13,44 < 1,997. Maka Ha diterima dengan hipotesis. Kebiasaan Menulis Buku Harian Dengan Menggunakan Model Pembelajaran Problem Based Learningpada Siswa Kelas VII Tahun Pembelajaran 2017/2018.
\end{abstract}

Kata Kunci : Problem Based Learning, Menulis, Kebiasaan Menulis Buku Harian

\section{PENDAHULUAN}

Berbahasamerupakansuatuketerampilan.Keterampilandapatdiperolehmelaluibelajardanbe rlatih.Melatihketerampuilanberbahasaberartimelatihketerampilanberfikir.Keterampilanberbahasa meliputiempataspekyakniketeramlanmenyimak, berbicara, membacadanmenulis. 
Keterampilan menulis yang tidak diimbangi dengan praktik menjadi salahsatu faktor kurang terampilnya siswa dalam menulis. Siswa pada sekolahmenengah atas seharusnya sudah dapat mengekspresikan gagasan,pikiran, dan perasaannya secara tertulis. Namun pada kenyataannya, kegiatanmenulis belum sepenuhnya terlaksana. Menyusun suatu gagasan, pendapat, danpengalaman menjadi suatu rangkaian berbahasa tulis yang teratur, sistematis, danlogis bukan merupakan pekerjaan mudah, melainkan pekerjaan yang memerlukan latihan terus-menerus.

Kebiasaan siswa menulis buku harian akan memudahkan siswa tersebut menuangkan perasaan dan isi hatinya ke dalam sebuah tulisan. Buku harian adalah buku yang berisi catatan pribadi atau jurnal sehari-hari. Kebiasaan anak menulis buku harian akan memudahkan anak tersebut menuliskannya dengan menggunakan metode problem based learning. Buku harian ditulis dengan bahasa sendiri (bahasa khusus/ bahasa sehari-hari) yang dipakai oleh penulisnya yang digunakan oleh seseorang untuk mengungkapkan sesuatu.

Ada banyak cara ataupun model yang dapat digunakan oleh pengajar dalam proses belajarmengajar. Salah satunya model Problem Based Learning(PBL) yang diartikan dalam bahasa Indonesia adalah pembelajaran berdasarkan masalah. Model ini adalah salah satu alternatif yang dapat meningkatkan pembelajaran di kelas. Pada model pembelajaran PBL, pelaksanaannya akan lebih memberikan ruang bagi siswa untuk dapat berpikir kritis dan kreatif dalam pembelajaran.

Model pembelajaran PBL merupakan model pembelajaran yang didasarkan pada banyaknya permasalahan yang membutuhkan penyelidikan autentik yakni penyelidikan yang membutuhkan penyelesaiannya dari permasalahan yang nyata. Pembelajaran ini umumnya dimulai dengan bagaimana siswa memikirkan penyelesaian suatu tugas, kemudian diikuti dengan mengomunikasikan hasil pemikirannya, dan akhirnya melalui diskusi, siswa dapat menuliskan kembali hasil pemikirannya. Dengan keterlibatan yang aktif ini, diharapkan akan dapat memberikan motivasi tersendiri untuk siswa dalam kegiatan menulis, sehingga kemampuan menulis buku harian menjadi lebih berkembang.

Peneliti menggunakan model pembelajaran Problem Based Learning untuk mempermudah siswa dalam mengembangkan inspirasi maupun gagasan yang akan dituangkan dalam menulis sebuah buku harian. Selain itu, proses belajar mengajar akan terasa lebih hidup dan lebih menyenangkan dibandingkan dengan menggunakan metode ceramah.Berdasarkan batasan masalah di atas maka rumusan masalah dalam penelitian ini adalah (1) Bagaimanakah kebiasaan menulis buku harian dengan menggunakan model pembelajaran problem based learning pada 
siswa kelas vii smp muhammadiyah 2 medan tahun pembelajaran 2017/2018? (2) Adakah pengaruh model pembelajaran Problem Based Learning terhadap kebiasaan menulis kebiasaan menulis buku harian pada siswa kelas vii smp muhammadiyah 2 medan tahun pembelajaran $2017 / 2018 ?$

\section{PEMBAHASAN}

\section{Hakikat Kebiasaan Menulis Buku Harian}

Buku harian adalah catatan kejadian yang kita alami sehari-hari. Menurut KBBI (Depdiknas,2008:218), "Buku harian adalah buku tulis yang berisi catatan atau kegiatan yang harus dilakukan dan kejadian yang dialami setiap hari." Sedangkan menurut Wikipedia (id.wikipedia.org/wiki/Bukuharian.), "Buku harian atau daiary adalah catatan kejadian yang kita alami sehari-hari. "Fungsi buku harian adalah sebagai kenangan yang pernah kita alami. Bisa juga sebagai momento/sejarah kehidupan kita. Seiring dengan perubahan zaman yang terlalu cepat sehingga perubahan tersebut membuat individu semakin stress entah dengan kariernya atau keluarganya, buku harianpun berubah fungsi dari sekedar menyimpan kenangan menjadi sebuah media untuk mencurahkan perasaan seseorang atas masalah yang dihadapinya. Beberapa manfaat buku harian antara lain:

a. Dapat menghilangkan stres dan mengurangi sedikit bahan pikiran.

b. Sebagai catatn target.

c. Sebagai sumber inspirasi.

d. Tempat menyimpan memori.

Kebiasaan menulis buku harian adalah kegiatan yang selalu dilakukan berupa menuangkan ide atau perasaan kedalam buku tulis baik itu catatan, kegiatan yang harus dilakukan, dan kejadian yang dialami setiap hari.

\section{Model Pembelajaran Problem Based Learning}

\section{a. Pengertian Model Pembelajaran Problem Based Learning}

Pengertian model pembelajaran Problem Based Learning (PBL) atau dalam bahasa Indonesia diartikan sebagai pembelajaran berbasis masalah merupakan pendekatan yang efektif untuk pengajaran proses berpikir tingkat tinggi. Pembelajaran ini membantu siswa untuk 
memproses informasi yang sudah jadi dalam benaknya dan menyusun pengetahuan mereka sendiri tentang dunia sosial dan sekitarnya. Ratumanan (dalam Trianto, 2011: 92).

Problem Based Learning (PBL) juga didefinisikan oleh Tan (dalamsRusman, (2012: 232) bahwa pembelajaran berbasis masalah merupakan penggunaan berbagai macam kecerdasan yang diperlukan untuk melakukan konfrontasi terhadap tantangan dunia nyata, kemampuan untuk menghadapi sesuatu yang kompleksitas yang ada.

Pengertian lainnya mengenai pengajaran berbasis masalah menurutArends (dalamTrianto, 2011:92) merupakan suatu pendekatan pembelajaran dimana siswa mengerjakan permasalahan yang autentik dengan maksud untuk menyusun pengetahuan mereka sendiri, mengembangkan inkuiri dan keterampilan berpikir tingkat lebih tinggi, mengembangkan kemandirian dan percaya diri.

\section{b. Konsep Problem Based Learning (PBL)}

Pembelajaran berbasis masalah (PBL) didasarkan atas teori psikologi kognitif, terutama berlandaskan teori Piaget dan Vigotsky (konstruktivisme). Menurut teori konstruksivisme, siswa belajar mengkonstruksi pengetahuannya melalui interaksi dengan lingkungannya. Pembelajaran berbasis masalah (PBL) dapat membuat siswa belajar melalui upaya penyelesaian permasalahan dunia nyata (real world problem) secara terstuktur untuk mengkonstruksi pengetahuan siswa. Penelitian ini menuntut siswa untuk aktif melakukan penyelidikan dalam menyelesaikan permasalahan dan guru berperan sebagai fasilitator atau pembimbing. Pembelajaran akan dapat membentuk kemampuan berpikir tingkat tinggi (higher order thinking) dan meningkatkan kemampuan siswa untuk berpikir kritis.

\section{c. Tujuan Model Pembelajaran Problem Based Learning}

Tujuan belajar dengan menggunakan PBL terkait dengan penguasaan materi pengetahuan, keterampilan menyelesaikan masalah, belajar multidisiplin, dan keterampilan hidup. Bagan keterkaitan permasalahan dengan tujuan pembelajaran dideskripsikan sebagai berikut Tan (dalam Sani, 2014: 129) 


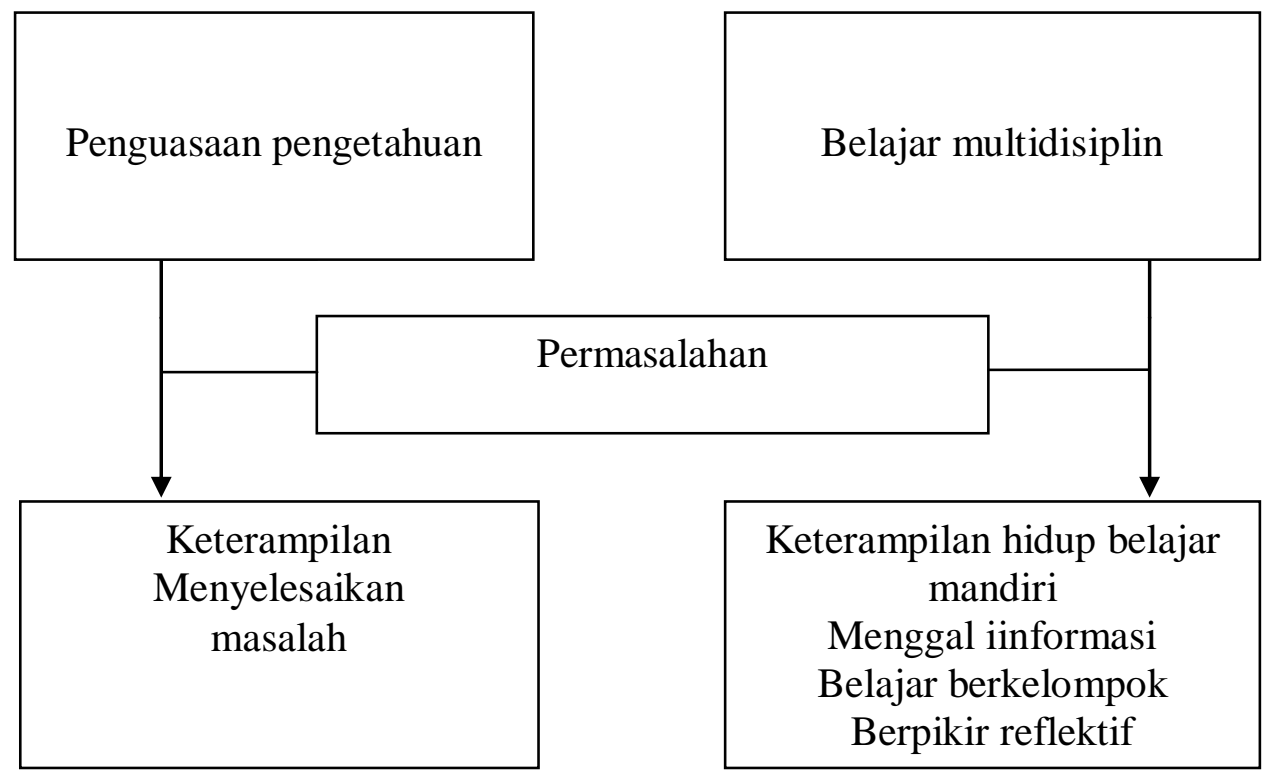

Gambar:Keterkaitan Permasalahan PBL dengan Tujuan Belajar

Rusman (2012:233) juga memberikan beberapa tujuan dari pembelajaran berbasis masalah, sebagai berikut:

1. Penguasaan isi pengetahuan yang bersifat multidisipliner.

2. Penguasaan keterampilan proses dan disiplin heuristik.

3. Belajar keterampilan pemecahan masalah.

4. Belajar keterampilan kehidupan yang lebih luas.

\section{d. Tahapan Pembelajaran dalam Problem Based Learning}

Pembelajaran dengan PBL seharusunya dimulai dengan menyajikan permasalahan kepada siswa. Tahap pertama yang dilakukan dalam pembelajaran adalah memotivasi peserta didik untuk terlibat dalam kegiatan penyelesaian masalah sehingga mereka akan bertindak aktif membangun pengetahuannya. Pemilihan permasalahan yang tepat akan meningkatkan keingintahuan siswa dan menimbulkan inkuiri dalam pikiran mereka. Penyelesaian masalah memerlukan analisis permasalahan dan indentifikasi pengetahuan yang telah mereka miliki, serta pengetahuan yang belum dikuasai.

Pelaksanaan PBL meliputi kegiatan antara lain:

1. Merumuskan tujuan pembelajaran. 
2. Memperoleh informasi baru melalui pembelajaran mandiri.

3. Menerapkan strategi/model baru dalam menganalisis permasalahan.

4. Mengajukan solusi permasalahan.

5. Mengkaji dan mengevaluasi solusi yang diterapkan.

\section{e. Kelebihan dan Kekurangan Model Pembelajaran Problem Based Learning}

Pembelajaran berbasis masalah memiliki kelebihan sebagai model pembelajaran menurut Trianto (2011: 96) adalah sebagai berikut:

1. Realistis dalam kehidupan siswa.

2. Konsep sesuai dengan kebutuhan siswa.

3. Memupuk sifat inquiri siswa.

4. Retensi konsep jadi kuat.

5. Memupuk kemampuan problem solving.

Selain itu Arends (dalamRiyanto, 2012: 287) juga mengidentifikasikankeunggulan model pembelajaran PBL adalah siswa lebih memahami konsep yang diajarkan sebab mereka sendiri yang menemukan konsep tersebut, yaitu:

1. Menuntut keterampilan berpikir tingkat tinggi untuk memecahkan masalah.

2. Pengetahuan tertanam berdasarkan skema yang dimiliki peserta didik sehingga pembelajaran lebih bermakna.

3. Peserta didik dapat merasakan manfaat pembelajaran.

4. Menjadikan peserta didik lebih mandiri, lebih dewasa dan termotivasi untuk memberi aspirasi dan menerima pendapat orang lain.

5. Pengkondisian peserta didik dalam belajar kelompok yang saling berinteraksi.

\section{f. Langkah-langkah Model Pembelajaran Problem Based Learning}

Menurut Ibrahim, dkk. (dalam Trianto, 2011: 98) menyatakan bahwa dalam pembelajaran berbasis masalah, terdapat beberapa langkah atau tahap-tahap yang perlu diketahui, yaitu:

a. Orientasi siswa pada masalah 

b. Mengorganisasi siswa untuk belajar
c. Membimbing penyelidikan individual maupun kelompok
d. Mengembangkan dan menyajikan hasil karya
e. Menganalisis dan mengevaluasi proses pemecahan masalah

\section{Metode Penelitian}

Metode penelitian memegang peranan yang sangat penting dalam suatu penelitian. Hal ini dikarenakan semua kegiatan yang dilaksanakan dalam penelitian sangat tergantung pada metode yang digunakan. Metode penelitian merupakan cara utama yang dipergunakan orang untuk mencapai tujuan penelitian.

Tujuan penelitian ini adalah untuk mengetahui kebiasaan menulis buku harian dengan menggunakan model pembelajaran Problem Based. Sesuai dengan tujuan penelitian di atas maka metode yang digunakan dalam penelitian ini adalah metode penelitian eksperimen. Sugiyono (2008: 14) mengatakan bahwa "Metode penelitian eksperimen merupakan metode penelitian yang digunakan untuk mencari pengaruh perlakuan tertentu”. Perlakuan diberikan pada dua kelas yaitu kelas eksperimen dan kelas kontrol.

Kelas eksperimen adalah kelas yang diberikan pembelajaran menggunakan model pembelajaran Problem Based Learning Sedangkan kelas kontrol adalah kelas yang diberi pembelajaran.

Metode eksperimen dipergunakan karena peneliti ingin menggambarkan hasil belajar siswa dengan menggunakanmodel pembelajaran Problem Based Learningdalam kemampuan menulis buku harian.

\section{HASIL PENELITIAN}

Hasil penelitian menunjukkan bahwa nilai siswa pada kelas eksperimen dan kelas kontrol mengalami perbedaan yang cukup signifikan. Hal tersebut menunjukkan hasil pembelajaran menggunakan model pembelajaran Problem Based Learning sudah mencapai nilai maksimal atau memenuhi kriteria ketuntasan minimum dengan nilai rata-rata siswa 83,84. Sedangkan kelas kontrol yang menggunakan metode ceramah nilai rata-rata siswa 63. Kemudian dilakukan 
pengujian hipotesis untuk hasil belajar dengan mengunakan uji-t. Setelah dilakukan pengujian data hasil belajar ternyata diperoleh hasil pengujian pada taraf $\alpha=0,05$ diperoleh $t_{\text {hitung }}>t_{\text {tabel }}$ yaitu $13,44>1,997$

Berdasarkan hasil hipotesis penelitian di atas dapat disimpulkan bahwa pembelajaran menulis buku harian dengan menggunakan model pembelajaran Problem Based Learning disarankan terhadap siswa karena mampu meningkatkan dan mempermudah siswa dalam proses belajar mengajar.

\section{SIMPULAN}

Penelitian ini bertujuan untuk mengetahui kebiasaan menulis buku harian dengan menggunakan model pembelajaran Problem Based Learning, disimpulkan bahwa, kebiasaan menulis buku harian dengan menggunakan model pembelajaran Problem Based Learning oleh siswa kelas VII SMP Muhammadiyah 2 Medan tahun pembelajaran 2017/2018 pada kelas eksperimen mendapatkan hasil paling dominan baik, dapat dibuktikan dengan persentase nilai 66-79 berjumlah 15 orang atau 39,47\%.Kemampuan menulis buku harian tanpa menggunakan model pembelajaran Problem Based Learning oleh siswa kelas VII SMP Muhammadiyah 2 Medan tahun pembelajaran 2017/2018 pada kelas kontrol mendapatkan hasil paling dominan kurang, dapat dibuktikan dengan persentase nilai 40-54 berjumlah 10 orang atau 33,33\%. Berdasarkan hal di atas dapat diambil kesimpulan bahwa penggunaan model pembelajaran Problem Based Learning dapat meningkatkan dalam kebiasaan menulis buku harian siswa. Hal ini ditandai dengan nilai $\mathbf{t}_{\text {hitung }}>\mathbf{t}_{\text {tabel }}\left(\mathbf{1 3 , 4 4}>\mathbf{1 , 9 9 7 )}\right.$ artinya nilai $\mathbf{t}_{\text {hitung }}$ lebih besar dari $t_{\text {tabel }}$ sehingga dapat disimpulkan bahwa penggunaan model pembelajaran Problem Based Learning.

\section{DAFTAR PUSTAKA}

Arikunto, Suharsimi. 2006. Prosedur Penelitian Suatu Pendekatan Praktik. Jakarta:RinekaCipta. Depdiknas.2007. Kamus Besar Bahasa Indonesia. Jakarta: Balai Pustaka. Riyanto, Yatim. 2012. Paradigma Baru Pembelajaran. Jakarta: Kencana. Rusman. 2012. Model-model Pembelajaran. Jakarta: Raja grafindo Persada. 
Sugiyono. 2008. Metode Penelitian Pendidikan. Bandung: Alfabeta.

. 2011. Metode Penelitian Pendidikan Kuantitatif, Kualitatif, dan $R \&$ D. Bandung:

Alfabeta

Tarigan, Hendry Guntur. 2005. Menulis Sebagai Suatu Keterampilan Berbahasa. Bandung: Angkasa Bandung.

Trianto.2011. Mendesain Model Pembelajaran Inovatif-Progresif. Jakarta: Kencana Prenada Media Group. 